\title{
Chemical Burn Injuries
}

\section{Kimyasal Yanıklar}

\author{
Ayten Saraçoğlü1, Mehmet Yılmaz², Kemal Tolga Saraçoğlü ${ }^{2}$
}

1Marmara Üniversitesi Tıp Fakültesi, Anesteziyoloji ve Reanimasyon Anabilim Dalı, İstanbul, Türkiye

2Sağlık Bilimleri Üniversitesi Tıp Fakültesi, Derince SUAM Anesteziyoloji ve Reanimasyon Kliniği, Kocaeli, Türkiye

\section{$\ddot{O Z E T}$}

Kimyasal yanıklar sıklıkla koroziv maddelere maruziyet sonrasında gelişmektedirler. Tüm yanık türlerinin \%10,7'sini, yanı merkezine hasta kabullerinin de \%2-6'sinı oluşturmaktadır. Kimyasal komponentlere bağlı hasar 6 farklı mekanizmayla ortaya çıkmaktadır. Bunlar redüksyon, oksidasyon, korozyon, protoplazmik toksinler, yakıcı kimyasallar ve kurutuculardır. Kimyasal yanık hasarının karakteristikleri arasında ciltte renk değişiklikleri ve korozyon, nadiren regüler bir yapı, gastrointestinal kanalda perforasyon, ciddi sistemik toksisite ve mortalite riski yer almaktadır. Termal yanıklarla karşılaştırıldığında yara iyileşme süreci belirgin derecede daha yavaş olup sıklıkla hastanede uzamış yatış süresiyle ilişkilidir. Ayrıca yanık hasarı genellikle kimyasal ajana uzamış maruziyet sonrasinda oluşmaktadır. Beyaz fosfor yanıkları bunun iyi bir örneğidir. Progresif nekroz. gelişen yanikların patogenezinde akla getirilmelidir. Acil resusitasyon hasar yönetiminde önceliklidir. Evde oluşan kazalardaysa sıklıkla sebep sivi amonyak ve nitrik asiddir. Kimyasal yanık hasarı tedavisinde halen altın standart yeterli miktarda su ile yaranın irrigasyonudur. Kimyasal yanık hasarı prevalansını azaltmaya amaçlı olarak koruyucu önlemlerin alınması önemlidir. Genel nüfus ve önleyici stratejilerin farkındalığını artırmak için medyanın tam desteğiyle ülke çapında kampanyalara ihtiyaç duyulmaktadır. Kamu spotları, medya organları, özel kuruluşlar, hekimler ve hastalar bu amaçla birlikte çalışmalıdırlar.

Anahtar Kelimeler: kimyasal yanı, hasar, mortalite

\begin{abstract}
Chemical burns often develop after exposure to corrosive substances. They include $10.7 \%$ of all burn types and 2-6\% of the patient admissions to the burn center. Chemical compounds possess 6 different types of damaging mechanisms; reduction, oxidation, corrosion, protoplasmic toxins, vesicants and desiccants. The characteristics of chemical burn injuries include skin discoloration and contractures, having rarely regular shape, perforation in the gastrointestinal tract with the risk of severe systemic toxicity and mortality. Compared to the thermal burns, the wound healing process following chemical burn injuries is markedly slower and also frequently related with a prolonged stay at the hospital. Moreover, generally the burn injury results following a prolonged exposure to the chemical agent. White phosphorus burns are good examples for this process. It should be considered in presence of burns with progressive necrosis. Emergency resuscitation is crucial for the management of injury. Most frequently observed agents in home injuries are liquid ammoniac and nitric acid. For chemical burn injuries the gold standart of treatment still is the irrigation of the wound with a copious amount of water. It is important to take protective measures in order to reduce the prevalence of chemical burn injury. Nation-wide campaigns with full support from the media are needed to raise awareness of the general population and preventive strategies. Public service broadcastings, media organs, trade unions, physicians and patients should work together for this purpose.
\end{abstract}

Keywords: chemical burn, injury, mortality

\footnotetext{
Iletişim / Correspondence:

Dr. Ayten Saraçoğlu

Marmara Üniversitesi Tıp Fakültesi, Anesteziyoloji ve Reanimasyon Anabilim Dall, Ístanbul, Türkiye

E-mail: anesthesiayten@gmail.com

Başvuru Tarihi:04.11.2017

Kabul Tarihi:22.01.2018
} 


\section{INTRODUCTION}

Chemical substances are commonly used as industrial products. There are over 5 million wellknown chemical compounds and 300 of them were reported by the National Fire Protection Association as chemicals with a very high level of health hazard (1). At the moment more than 65000 different types of chemical substances are present on the market and approximately 6000 new types are added them each year. Direct exposure to some of these chemical agents unevitably result in chemical burn injury.

\section{Incidence and outcomes}

Chemical burns constitute roughly $10.7 \%$ of all burn injuries, $2-6 \%$ of all burn-center admissions (2) and $30 \%$ of all burn-related deaths (3). The epidemiological features of chemical burn injuries vary among different countries; but they also display domestic differences in a specific country according to the geographical location, neighbouring industrial developments and even the military state of that country being at war or at peace (4). On the other hand the uncontrolled expansion of chemical weapons in the developing countries constitutes one of the primary reasons for the increase in burn injuries. Thus the epidemiological studies of various countries and regions are of importance both for preventive and educational purposes. There are some study results on chemical burn injuries in Turkey but these studies are either confined to children $(5,6)$ or they reflect only the eastern part of the country (7).

\section{Types of chemical injuries}

Chemical compounds possess 6 different types of damaging mechanisms; reduction, oxidation, corrosion, protoplasmic toxins, vesicants and desiccants (2). Chemicals can be classified as acid, alkali, organic and inorganic compounds. Alkaline compounds cause liquefactive necrosis on the surface epitelium of the skin whereas acid tends to penetrate into deeper levels. Acid-related burns result in release of hydrogen ions which in turn cause coagulative necrosis; additionally they also induce dry necrosis thanks to their water absorbing properties (8). They are frequently utilized in various fields including pharmaceutical industry, agricultural practice, paint industry and cleaning solution manufacturing. On the other hand, the unrestrained rise in the armament rate of chemical weapons of mass destruction constitutes one of the primary reasons for the increased rate of burn injuries. There are many types of chemicals with various features and potency thus exposure to them results in a broad spectrum of burn injuries ranging from mild burns to life-threatening ones. Some of these burn injuries respond to medical treatment while others may require surgical intervention.

Compared to the thermal burns, the wound healing process following chemical burn injuries is markedly slower and also frequently related with a prolonged stay at the hospital (9). Moreover, the burn injury results following a prolonged exposure to the chemical agent. White phosphorus burn is a good example for this process (10). It should be considered in presence of burns with progressive necrosis. Emergency resuscitation is crucial and simple for the management of injury.

There are various other factors affecting the intensity of a burn damage including the concentration of the chemical agent, the amount of the burning substance, the duration of skin contact, the penetration and the mechanism of action. Under certain circumstances the primary chemical reaction still goes on even after the arrival of the patient in the emergency room (11). The damage of the chemical burn injuries most frequently occur on the skin and in the digestive system (12).

Compared to other types of burn injuries chemical burns occur relatively rarely, nevertheless they mostly produce serious damage on the deep tissue level. The burned tissues usually involve muscles, tendons, articular capsules and organs situated on deeper levels. The relatively lower incidence of chemical burns results in burn cases with occasionally missed diagnosis, poor management or inaccurate treatment applications due to the lack of experience of the health professionals. The deeper involvement of the damaged tissues and its serious implications on the patients health result in a prolonged rehabilitation period with an obvious rise in medical costs. Thus especially at the working places the augmentation of the preventive measures and the appropriate training of the physicians and the workers gained particular importance in the recent years. These patients need to be referred as 
soon as possible to a burn center where a burn team specialized in this type of injury is going to take care of them.

Xie et al. (13) reported male predominance among patients with chemical burn injuries. The general tendency of male population to have a physically more demanding occupation with a relatively greater risk for injury is suggested as the main reason behind this gender-specific difference. $42.2 \%$ of the patients in the study led by Xie et al. have been operated. The presence of a more experienced team immediately following the incident or during the transport of patient from another medical center could successfully decrease the application rate of surgery and shorten the postoperative rehabilitation period.

Some of the studies reported in the literature exhibit national variability. In Taiwan (14) and Tasmania (15) most of the victims were male; on the other hand, no significant difference was found between male and female patients in Jamaica (16). The incidence of chemical burn injuries was reported to exhibit a peak in spring and summer (3). However a study led by Kai-yang et al. (17) was unable to demonstrate a seasonal pattern. Acid burns has been most commonly observed in workers of the coating industry whereas alkali burn injuries most frequently happened in soap manufacturing industry. Among the patients admitted to the hospital, negligence, carelessness and underestimation of the possible consequences are generally the most frequent causes of injury. Although have been previously warned verbally and through several precaution signs on the walls, construction workers may still fail to wear gloves, boots and caps most of the time. Thus, following any accident which takes place during production and transport stages of the corrosive agents burn injury ensues.

Most frequently observed agents in home injuries are liquid ammoniac and nitric acid. This is especially true for those patients transported from eastern part of Turkey or family members with a history of emigration from east Turkey. These solutions are rather cheap thus they are usually bought in huge amounts, stored in recycled plastic bottles and used for house cleaning in communities with a low socioeconomic status. Liquid nitric acid also is a frequently used solution to clear clogged waste pipes. This corrosive agent is a cheap and easily-found product in local stores and supermarkets. The 'traditional usage' of such chemicals can easily give rise to severe consequences, especially for the pediatric age group. When these children are left unattended and the plastic bottles are within their reach they can easily end up with ingesting these chemical solutions. Nation-wide campaigns with full support from the media are needed to raise awareness of the general population and preventive strategies have to be applied promoting the cessation of the aforementioned dangerous practices. Those children admitted to the hospital with ingestion of a corrosive agent face a difficult medical course starting with upper gastrointestinal system endoscopy, many successive dilatation procedures, prolonged hospital stays and resulting in growth retardation. These injuries have negative influences not only on the psychological and physiological development of the patients but also on the national economy.

\section{Treatment and cautions}

For chemical burn injuries the gold standart of treatment still is the irrigation of the wound with a copious amount of water (11). In conjunction with several other studies reported in the literature the sulphuric acid constituted one of the prevalent causes of acid burn injuries in our study $(18,19)$. Industrial workers are frequently exposed to sulphuric acid, which is a cheap chemical agent often utilized in car batteries and the leather industry. It is also handled in many laboratories, cleaning material producing factories and in the textile industry. One of the major issues noted in several studies is the fact that many victims have no idea what he/she has to do following the exposure to a chemical agent. The immediate removal of the contaminated clothes and the irrigation of the wound with copious amount of water are sometimes life-saving (20). Terror assaults constitute one other important risk factor in developing countries and chemical agents are among the various weapons of mass destruction. Regenerating agents (RGTAs) are effectively used biological agents for the treatment 
of corneal epithelial defects following severe ocular chemical injuries (21).

Among many other details one should also mention about some extreme cases of chemical burn injuries reported in the literature. These extreme events include povidone iodine related burn injury following perioperative inflation of the tourniquet (5), active sterilization agent related caustic burn injury by ECHO probe on the esophagus, sterilization of noninvasive blood pressure cuff with ethylene oxide (6), lime exposure of a professional goalkeeper (19), chemical burn injury following the application of wood ash as a traditional method and dermal injury following direct contact with gastric content.

\section{CONCLUSION}

The characteristics of chemical burn injuries include discoloration and contractures, having rarely regular shape, perforation in the gastrointestinal tract with the possibility of severe systemic toxicity and mortality (22). Preventive measures need to be undertaken at once in order to lower the prevalence of chemical burn injuries in our society and to improve its adverse consequences. Joint information and prevention programs have to be organized for participation of the representatives of the government, media organs, trade unions, physicians and patients. All chemical agents should be stored in safe, well ventilated places and be kept away from children at all times. The sales and marketing rights of certain chemical agents to the general population should be restricted.

\section{REFERENCES}

1. Barillo DJ, Cancio LC, Goodwin CW. Treatment of white phosphorus and other chemical burn injuries at one burn center over a 51year period. Burns 2004; 30(5):448-52.

2. Ahmadi H, Durrant CAT, Sarraf KM, et al. Chemical burns: A review. Trends Anaesthesia \& Critical Care 2008; 19(5-6):282-6.

3. Maghsoudi H, Gabraely N. Epidemiology and outcome of 121 cases of chemical burn in East Azarbaijan province, Iran. Injury 2008; 39(9):10426.
4. Pitkanen J, Al-Qattan MM. Epidemiology of domestic chemical burns in Saudi Arabia. Burns 2001; 27(4):376-8.

5. Doğan Y, Erkan T, Cokuğraş FC, et al. Caustic gastroesophageal lesions in childhood: an analysis of 473 cases. Clin Pediatr (Phila) 2006; 45(5):4358.

6. Gün F, Abbasoğlu L, Celik A, et al. Early and late term management in caustic ingestion in children: a 16-year experience. Acta Chir Belg 2007; 107(1):49-52.

7. Coban YK, Erkiliç A, Analay H. Our 18month experience at a new burn center in Gaziantep, Turkey. Ulus Travma Acil Cerrahi Derg 2010; 16(4):353-6.

8. Kozawa S, Kakizaki E, Muraoka E, et al. An autopsy case of chemical burns by hydrochloric acid. Leg Med (Tokyo). 2009; 11(1):S535-7.

9. Rice P. Sulphur Mustard Injuries of the Skin: Pathophysiology and Management Toxicological Reviews 2003; 22(2):111-8.

10. Saracoglu KT, Acar AH, Kuzucuoglu T, et al. Delayed diagnosis of white phosphorus burn. Burns 2013; 39(4):825-6.

11. Palao R, Monge I, Ruiz M, et al. Chemical burns: pathophysiology and treatment. Burns 2010; 36(3):295-304.

12. Pavelites JJ, Kemp WL, Barnard JJ, et al. Deaths related to chemical burns. Am J Forensic Med Pathol 2011; 32(4):387-92.

13. Xie Y, Tan Y, Tang S. Epidemiology of 377 patients with chemical burns in Guangdong province. Burns 2004; 30(6):569-72.

14. Chou TD, Lee WT, Chen SL, et al. Split calvarial bone graft for chemical burn-associated nasal augmentation. Burns 2004; 30(4):380-5.

15. Ricketts S, Kimble FW. Chemical injuries: the Tasmanian Burns Unit experience. ANZ J Surg 2003; 73(1-2):45-8.

16. Merle H, Donnio A, Ayeboua L, et al. Alkali ocular burns in Martinique (French West Indies) Evaluation of the use of an amphoteric solution as the rinsing product. Burns 2005; 31(2):205-11. 
17. Kai-Yang L, Zhao-Fan X, Luo-Man Z, et al. Epidemiology of pediatric burns requiring hospitalization in China: a literature review of retrospective studies. Pediatrics 2008; 122(1):13242.

18. Diarra B, Roudie J, Ehua Somian F, et al. Caustic burns of rectum and colon in emergencies. Am J Surg. 2004; 187(6):785-9.

19. Ogunleye AO, Nwaorgu GB, Grandawa $H$. Corrosive oesophagitis in Nigeria: clinical spectrums and implications. Trop Doct 2002; 32(2):78-80.

20. Milton R, Mathieu L, Hall $\mathrm{AH}$, et al. Chemical assault and skin/eye burns: two representative cases, report from the Acid Survivors Foundation, and literature review. Burns 2010; 36(6):924-32.

21. Ustaoglu M, Solmaz N, Onder F. Ocular surface chemical injury treated by regenerating agent (RGTA, Cacicol20). GMS Ophthalmol Cases 2017;7:Doc28.

22. Dinis-Oliveira RJ, Carvalho F, Moreira R. Clinical and forensic signs related to chemical burns: a mechanistic approach. Burns 2015;41(4):658-79. 